\title{
ANALISIS PERENCANAAN KAPASITAS PRODUKSI DENGAN MENGGUNAKAN METODA ROUGHT CUT CAPACITY PLANNING PENDEKATAN CPOF DI PT. XYZ
}

\author{
Angling Sugiatna \\ Program Studi Teknik Industri \\ Sekolah Tinggi Teknologi Bandung \\ anglingsugiatna2020@gmail.com
}

\begin{abstract}
Abstrak
Perencanaan kapasitas merupakan salah satu tahapan dalam rangkaian perencanaan sistem produksi. Perencanaan kapasitas menjadi penting, karena berfungsi untuk mengetahui, sampai sejauh mana kapasitas yang dimiliki bisa memenuhi kapasitas yang dibutuhkan. Oleh karena itu perlu dilakukan analisis kelayakan terhadap kapasitas produksi pada semua stasiun kerja yang ada dengan metode rough cut capacity planning (RCCP). Ada beberapa tahapan yang dilakukan dalam analisis kelayakan kapasitas. Tahap pertama adalah menghitung kapasitas tersedia setiap stasiun kerja. Selanjutnya dilakukan perhitungan kapasitas yang dibutuhkan setiap stasiun kerja. Tahapan terakhir adalah uji kelayakan kapasitas dengan membandingkan kapasitas tersedia dengan kapasitas yang dibutuhkan. Berdasarkan perhitungan Rough Cut Capacity Planning menggunakan metode CPOF dapat dilihat bahwa berdasarkan MPS tahun 2022, 4 bulan kapasitas tersedia bisa memenuhi kapasitas dibutuhkan atau sekitar 33\%, sedangkan 77\%, kapasitas tersedia tidak bisa memenuhi kapasitas dibutuhkan. Hal ini menunjukkan bahwa kapasitas yang tersedia tidak dapat memenuhi kebutuhan kapasitas atau dengan kata lain kapasitas yang dibutuhkan jauh lebih besar dari kapasitas tersedia yang dimiliki oleh perusahaan.
\end{abstract}

Kata kunci : Kapasitas, MPS, RCCP

\begin{abstract}
Capacity planning is one of the stages in a series of production system planning. Capacity planning is important, because it serves to determine to what extent the existing capacity can meet the required capacity. Therefore, it is necessary to conduct a feasibility analysis of the production capacity at all existing work stations using the rough cut capacity planning $(R C C P)$ method. There are several stages carried out in the capacity feasibility analysis. The first stage is to calculate the available capacity of each work station. Furthermore, the calculation of the capacity required for each work station is carried out. The last stage is a capacity feasibility test by comparing the available capacity with the required capacity. Based on the calculation of the Rough Cut Capacity Planning using the CPOF method, it can be seen that based on the MPS in 2022, 4 months of available capacity can meet the required capacity or about 33\%, while $77 \%$, the available capacity cannot meet the required capacity. This shows that the available capacity cannot meet the capacity needs or in other words the required capacity is much greater than the available capacity owned by the company.
\end{abstract}

Keywords : Capacity, MPS, RCCP

\section{PENDAHULUAN}

Furnitur merupakan terminologi yang digunakan untuk perabotan rumah tangga yang berfungsi untuk menyimpan barang, tempat duduk, tempat tidur, tempat untuk menulis sesuatu berupa meja atau tempat meletakkan sesuatu di atasnya. Sebagai contoh, furnitur yang berfungsi untuk menyimpan pada umumnya dilengkapi dengan pintu, laci dan rak, seperti lemari buku, lemari pakaian, dan lain-lain. Furnitur biasanya memiliki tekstur dan warna yang indah yang disebabkan oleh proses akhir yang halus [2]. Industri furnitur merupakan industri yang mencakup pengolahan bahan baku berupa kayu, logam, rotan, atau bahan baku lainnya yang diproses untuk meningkatkan nilai tambah dan manfaat yang lebih tinggi menjadi produk barang jadi furnitur [1].

PT. XYZ merupakan salah satu produsen atau pabrik yang menghasilkan produk furnitur berbahan logam. PT. XYZ termasuk salah satu perusahaan market leader, khususnya dibidang penjualan produk furnitur berbahan baku logam. Hampir $70 \%$, penjualannya untuk memenuhi pasar domestik, dan 30\% untuk memenuhi pasar ekspor. Pada tahun 2014, PT. XYZ berubah bentuk menjadi perusahaan terbuka dan sebanyak delapan kali berturut-turut sejak tahun 2012, telah meraih penghargaan top brand untuk kategori office chair dan folding chair [4]. Dengan berbagai capaian yang sudah diraih oleh PT. XYZ sampai saat ini, maka aspek kepuasan pelanggan menjadi salah satu komponen penting yang harus dipertahankan.

Permasalahan yang muncul, pada saat perusahaan menerima pesanan konsumen, sering kali tidak mempertimbangkan sumber daya kapasitas produksi yang tersedia. Permintaan yang melebihi kapasitas akan mengakibatkan produk yang dibuat tidak selesai tepat waktu.

Oleh karena itu PT. XYZ perlu membuat jadwal induk produksi sebagai dasar penentuan jadwal proses operasi dan jadwal alokasi sumber daya untuk mendukung penyelesaian pemesanan tepat waktu. Dengan dibuatnya jadwal induk produksi, perusahaan dapat melakukan kegiatan produksi dengan terencana dan terkendali sehingga penyelesaian produk tepat waktu dengan jumlah yang banyak. 
Adapun tujuan yang ingin dicapai dalam penelitian ini adalah untuk mengetahui kebutuhan kapasitas produksi pada setiap work centre dengan rough cut capacity planning di PT. XYZ.

\section{TINJAUAN PUSTAKA}

1. Kapasitas

Kapasitas merupakan sebagai jumlah output maksimum yang dapat dihasilkan suatu fasilitas produksi dalam suatu selang waktu tertentu. Kapasitas merupakan suatu tingkat keluaran dalam periode tertentu dan merupakan kuantitas keluaran tertinggi yang mungkin selama periode itu. Kapasitas dapat disesuaikan dengan tingkat penjualan yang sedang berfluktuasi yang dicerminkan dalam jadual induk produksi (master production schedule/MPS).

Apabila terjadi kelebihan kapasitas sudah pasti operasional produksi tidak efisien dikarenakan stasiun yang jarang bekerja penuh atau sering menganggur. Begitu pula apabila stasiun mengalami kekurangan kapasitas maka tentu target yang diinginkan perusahaan tidak akan dalam suatu periode waktu tertentu[3].

Terdapat dua jenis pengertian kapasitas yang dianggap penting yaitu kapasitas yang tersedia dan kapasitas yang dibutuhkan. Kapasitas yang tersedia adalah kapasitas dari suatu sistem yang ada untuk memproduksi suatu jumlah keluaran dalam waktu tertentu, sedangkan kapasitas dibutuhkan adalah kapasitas dari suatu sistem yang dibutuhkan untuk memproduksi suatu jumlah keluaran dalam suatu waktu tertentu. Istilah ketiga yang erat hubungannya dengan kapasitas dibutuhkan adalah muatan (load). Load adalah jumlah pekerjaan yang ditugaskan atau dibebankan pada suatu fasilitas untuk diselesaikan dalam suatu waktu tertentu.

\section{Rough Cut Capacity Planning (RCCP)}

Rough Cut Capacity Planning (RCCP) merupakan metode yang digunakan untuk mengukur kapasitas stasiun kerja sehingga dapat diketahui apakah suatu jadwal produksi memerlukan kerja lembur, subkontraktor, ataupun strategi produksi lainnya, untuk memenuhi permintaan yang tepat waktu.

Rough Cut Capacity Planning (RCCP) juga merupakan proses menentukan apakah sumberdaya yang direncanakan cukup untuk melaksanakan MPS. Kelancaran produksi dalam suatu pabrik sangat penting, karena jika terjadi kemacetan dalam suatu proses produksi hal ini dapat mengakibatkan penumpukan bahan baku ataupun meningkatnya Work in Process dalam memproduksi suatu barang.

Keberhasilan perencanaan manufakturing membutuhkan perencanaan kapasitas yang efektif agar mampu memenuhi jadwal produksi yang telah ditetapkan. Kekurangan kapasitas akan menyebabkan kegagalan memenuhi target produksi, keterlambatan pengiriman ke pelanggan dan kehilangan kepercayaan dalam sistem formal yang mengakibatkan reputasi perusahaan akan menurun bahkan hilang sama sekali.

Rough Cut Capacity Planning (RCCP) menentukan apakah sumber daya yang direncanakan cukup untuk melaksanakan MPS. RCCP bertujuan menghitung beban untuk semua item yang dijadwalkan dan dalam periode waktu yang aktual. Jika proses RCCP mengindikasikan bahwa MPS layak dilaksanakan maka MPS akan diteruskan ke proses MRP guna menentukanbahan baku atau material, komponen dan subassemblies yang dibutuhkan.

\section{Teknik-Teknik Dalam Penerapan RCCP}

a. Capacity Planning Using Overall Factors (CPOF)

CPOF merupakan perencanaan yang relatif kasar, dengan input yang diperlukan seperti: MPS, waktu total pabrik yang diperlukan untuk memproduksi satu part tertentu dan proporsi historis yakni perbandingan antar stasiun kerja mengenai kapasitas produk pada waktu tertentu. Cara erhitungannya relatif mudah, dengan mengalikan proporsi historis dengan total kuantitas MPS pada periode tertentu untuk masing-masing stasiun kerja. Dari hasil perhitungan ini nantinya diperoleh waktu total yang diperlukan, total waktu ini kemudian dirata-ratakan dan dibandingkan dengan waktu kapasitas.

b. Bill of Labor Approach (BOL)

Bill of Labor Approach didefinisikan sebagai suatu daftar yang berisi jumlah tenaga kerja yang dibutuhkan untuk memproduksi suatu item. Pendekatan dengan teknik ini menggunakan data yang rinci mengenai waktu baku setiap produk pada sumber-sumber utama. Ada masukan yang dibutuhkan untuk pendekatan BOL, yaitu: MPS dan Bill of Labor.

c. Resources Profile Approach

Pendekatan ini juga menggunakan data waktu baku. Selain itu membutuhkan pula data lead time yang diperlukan pada stasiun-stasiun kerja tertentu. 
III. ANALISA DAN PEMBAHASAN

Tabel I menunjukkan data Jadwal Induk Produksi (MPS) Periode Bulan Januari sampai Desember Tahun 2022 PT. XYZ.

TABEL 1

DATA JADWAL INDUK PRODUKSI TAHUN 2022 PT. XYZ

\begin{tabular}{|l|r|r|}
\hline \multicolumn{1}{|c|}{ Bulan } & MPS (Unit) & \multicolumn{1}{c|}{ Hari Kerja } \\
\hline Januari & 17.056 & 21 \\
\hline Pebruai & 14.235 & 18 \\
\hline Maret & 13.987 & 22 \\
\hline April & 13.590 & 20 \\
\hline Mei & 13.618 & 12 \\
\hline Juni & 19.874 & 21 \\
\hline Juli & 26.653 & 21 \\
\hline Agustus & 26.267 & 22 \\
\hline September & 27.642 & 22 \\
\hline Oktober & 26.634 & 21 \\
\hline Nopember & 25.236 & 22 \\
\hline Desember & 26.563 & 22 \\
\hline Total & $\mathbf{2 5 0 . 0 2 9}$ & $\mathbf{2 4 4}$ \\
\hline
\end{tabular}

Informasi tambahan :

Jam kerja $=8$ jam/hari

Jumlah shift $=1$ shift

Efisiensi $=95 \%$

Sementara Tabel II menunjukkan data waktu proses untuk setiap stasiun kerja.

TABEL II

DATA WAKTU PROSES SETIAP STASIUN KERJA

\begin{tabular}{|c|l|r|}
\hline No & WORK STATION & MENIT \\
\hline 1 & Bending & 1,73 \\
\hline 2 & Las & 1,94 \\
\hline 3 & Finishing & 3,00 \\
\hline 4 & Nailing & 1,02 \\
\hline 5 & Perangkaan & 1,62 \\
\hline 6 & Assembling & 2,27 \\
\hline \multicolumn{2}{|c|}{ JUMLAH } & 11,58 \\
\hline
\end{tabular}

1. Perhitungan Kapasitas Dibutuhkan

Perhitungan kapasitas yang dibutuhkan dengan metode CPOF menggunakan rumus sebagai berikut :

- $\quad$ Kapasitas Dibutuhkan $(K D)=$ Total Waktu Proses x Jadwal Induk Produksi

$=$ TWP $\mathrm{x}$ JIP (menit unit)

Contoh perhitungan kebutuhan kapasitas total bulan Januari 2022 yaitu:

$\mathrm{KDT}_{\text {Jan }}=$ TWP $\times \mathrm{JIP}_{\mathrm{Jan}}$

$=11,58$ menit $\times 17.056$ unit $=197.511$ menit 
- Contoh perhitungan kebutuhan kapasitas pada bulan Januari untuk stasiun kerja Bending (BD) yaitu: $\mathrm{KD}(\mathrm{Jan}) \mathrm{BD}=$ Proporsi $\mathrm{x}$ Kebutuhan kapasitas total Bulan Januari

$=\mathrm{P}_{\mathrm{Jan}} \times \mathrm{KDT}_{\mathrm{Jan}}$

$=0,1494 \times 197.511=29.507$ menit

Untuk hasil perhitungan bulan Pebruari sampai Desember 2022, dapat dilihat di tabel III.

2. Perhitungan Kapasitas Tersedia

Perhitungan kapasitas yang tersedia dengan metode CPOF digunakan rumus sebagai berikut: efesiensi.

Kapasitas tersedia $(\mathrm{KD})=$ jumlah mesin /manpower $\mathrm{x}$ jumlah shift $\mathrm{x}$ jam kerja $\mathrm{x}$ jumlah hari kerja $\mathrm{x}$ utilitas $\mathrm{x}$

Berikut ini contoh perhitungan kapasitas tersedia pada stasiun kerja Bending (BD) untuk bulan Januari 2022 :

$\mathrm{KD}=5 \times 1 \times 8 \times 21 \times 95 \%=47.880$ menit

Untuk hasil perhitungan bulan Pebruari sampai Desember 2022, dapat dilihat di tabel 3.

TABEL III

HASIL PERHITUNGAN KAPASITAS TERSEDIA DAN KAPASITAS DIBUTUHKAN TAHUN 2022

\begin{tabular}{|c|c|c|c|c|c|c|c|c|c|c|c|c|c|}
\hline \multirow{2}{*}{ No } & \multirow{2}{*}{ Stasiun Kerja } & \multicolumn{12}{|c|}{ Bulan } \\
\hline & & Januari & Pebruari & Maret & April & Mei & Juni & Juli & Agustus & September & Oktober & Nopember & Desember \\
\hline 1 & Bending & 29.507 & 24.626 & 24.198 & 23.510 & 23.559 & 34.383 & 46.110 & 45.442 & 47.821 & 46.077 & 43.658 & 45.954 \\
\hline 2 & Las & 33.089 & 27.616 & 27.135 & 26.364 & 26.418 & 38.556 & 51.707 & 50.958 & 53.625 & 51.670 & 48.958 & 51.532 \\
\hline 3 & Finishing & 51.169 & 42.705 & 41.962 & 40.769 & 40.853 & 59.623 & 79.959 & 78.802 & 82.926 & 79.902 & 75.708 & 79.689 \\
\hline 4 & Nailing & 17.397 & 14.520 & 14.267 & 13.862 & 13.890 & 20.272 & 27.186 & 26.793 & 28.195 & 27.167 & 25.741 & 27.094 \\
\hline 5 & Perangkaan & 27.631 & 23.061 & 22.659 & 22.015 & 22.061 & 32.197 & 43.178 & 42.553 & 44.780 & 43.147 & 40.882 & 43.032 \\
\hline 6 & Assembling & 38.718 & 32.313 & 31.751 & 30.849 & 30.912 & 45.115 & 60.502 & 59.627 & 62.747 & 60.459 & 57.286 & 60.298 \\
\hline $\mathrm{Dil}$ & $\begin{array}{l}\text { Kapasitas } \\
\text { tuhkan (menit) }\end{array}$ & 197.511 & 164.841 & 161.973 & 157.369 & 157.694 & 230.146 & 308.641 & 304.174 & 320.094 & 308.422 & 292.233 & 307.600 \\
\hline & $\begin{array}{l}\text { asitas Tersedia } \\
\text { (menit) }\end{array}$ & 268.128 & 229.824 & 280.896 & 255.360 & 153.216 & 268.128 & 268.128 & 280.896 & 280.896 & 268.128 & 280.896 & 280.896 \\
\hline
\end{tabular}

Berdasarkan tabel III, terlihat bahwa ada dua kondisi yang berkaitan dengan hubungan kapasitas tersedia dan dibutuhkan. Pertama, adanya stasiun kerja yang kelebihan kapasitas, kedua, adanya stasiun kerja yang kekurangan kapasitas.

3. Kelebihan Kapasitas

Pada bulan Januari sampai April terjadi kelebihan kapasitas, rekomendasi yang dilakukan :

a. Menarik pekerjaan yang dilakukan di subkon, untuk menekan cost per unit

b. Memproduksi sesuai kebutuhan pihak sales

c. Mengurangi jam operasional pabrik, sesuai kebutuhan

d. Preventif maintenance dilakukan di jam normal

e. Menurunkan waktu setting mesin

4. Kekurangan Kapasitas

Pada bulan Mei sampai Desember 2022 terjadi kekurangan kapasitas, rekomendasi yang dilakukan :

a. Revisi MPS, dengan melakukan pergeseran dari bulan yang kelebihan kapasitas ke bulan yang kekurangan kapasitas

b. Melakukan overtime, untuk menutupi kekurangan kapasitas jam regular.

c. Memberlakukan system shift

d. Sebagian pekerjaan dikerjakan disubkon

e. Memanfaatkan stok barang jadi, dengan mensubtitusikan barang yang sama, tapi beda warna

f. Penambahan SDM, jika strategi tersebut memang benar-benar dibutuhkan 


\section{SISTEMIK(Jurnal Ilmiah Nasional Bidang Ilmu Teknik)}

Vol. 09 No. 02 Desember 2021

P-ISSN : 2337-3636 || E-ISSN : 2527-6425

\section{KESIMPULAN}

Berdasarkan hasil pengolahan data dan analisa dengan menggunakan Rough Cut Capacity Planning di PT. XYZ, maka dapat diambil kesimpulan sebagai berikut :

1. Kapasitas yang tersedia untuk memenuhi kapasitas dibutuhkan di Tahun 2022 berdasakan hasil perhitungan Rough CutCapacity Planning menggunakan metode CPOF, terlihat bahwa MPS yang direncanakan oleh perusahaan tidak layak, karena hanya ada 4 bulan dari 12 bulan, dimana kapasitas tersedia lebih besar dibanding kapasitas dibutuhkan, atau sekitar $33 \%$.

2. Data permintaan konsumen cenderung naik mulai dari pertengahan tahun sampai akhir tahun.

3. Jadwal Induk Produksi yang dibuat, tidak bisa memenuhi permintaan konsumen

\section{REFERENSI}

[1] Asosiasi Mebel dan Kerajinan Indonesia (AMKRI). (2015). Roadmap Industri Mebel dan Kerajinan Indonesia "Target Pencapaian Ekspor 5 Milyar USD". Jakarta

[2] Bank Indonesia, 2008. Pola Pembiayaan Usaha Kecil (PPUK) Furnitur Kayu.

[3] Heizer, Jay. Render, Barry. Munson, C. (2017). Operations management: sustainability and supply chain management. Journal of purchasing and supply management.

[4] Fokus dan kolaborasi. Topbrand-award.com. 20 Mei 2020. 15 Nopember 2021. https://www.topbrand-award.com/2020/05/kuncinya-fokusdan-kolaborasi/ 